\title{
NOTES ON RECENT CASES,
}

\section{Nationatity-Divestment DuRing War-"National" in Treaty of Peace-British Nationality and Status of Aliens Act, 1914.}

In re Chamberlain's Settlement; Chamberlain v. Chamberlain.

[1921]

2 Ch. 533. Fasbender v. Attorney-General. [1922] 1 Ch. 232.

IN these cases further consideration was given to the principles established in Rex. v. Lynch [1903] 1 K. B. 444, and Rex v. C. O. 30th Batt. Middlesex Regt., Ex parte Freyberger [1917] 2 K. B. 129.

A fund was vested in the plaintiffs in the former summons as trustees, to invest and pay the income to the defendant during his life or until he should become bankrupt or assign or charge it or " until some other event should happen... whereby the said income or any part thereof if belonging absolutely to him would become vested in or charged in favour of some other person or persons or a corporation"; and, in the event of determination of this trust during the life of the defendant, to apply the insome during the rest of his life, at their discretion, for the benefit of the defendant and certain other persons.

The defendant was a natural-born British subject, but during the war he obtained a certificate of naturalization as a German. It was admitted that by German law he thereby became a German subject.

By the Treaty of Peace, 1918, Article 287, and the Treaty of Peace Order, 1919, s. 1, cl. xvi., the property within His Majesty's Dominions belonging to "German nationals" at the date when the Treaty came into force-namely, January 10, 1920 - was charged with certain payments, and by section 2 of the Order the expression "nationals" in relation to any State was to include for the purposes of the Order " the subjects or citizens of that State... according to the law of that State."

Under these sections it was held by P. O. Lawrence, J., that the defendant was, for the purposes of the Order, a German national, and that the income of the trust would accordingly have been subjected to a charge, if it had belonged to him absolutely. The trust in favour of the defendant was therefore determined on January 10,1920 , and the subsequent income was to be applied to the discretionary trust.

This decision in no way conflicts with those in $R$. v. Lynch and $E x$ parte Freyberger. By English law a British subject cannot by naturalization or declaration of alienage divest himself of British nationality during a time of war and become solely a subject of an enemy State. By English law the defendant's act of naturalization was void and illegal, and he remained a British subject. The possession of British nationality does not, however, exempt anyone from liability under the Treaty of Peace Order; the only material factor for this purpose is whether a person is by German law a German subject, whatever other nationality he may possess.

In Fasbender v. Attorney-General a similar question arose, and Russell, J., followed the decision of P. O. Lawrence, J. The primary ground of the former's judgment, however, involves a deeper consideration of the earlier cases. The facts in this summons were that the plaintiff, after the signing of the Treaty of Peace, but before January 10, 1920 (when it came into force), being then a British subject, went to Germany 
and married a German subject. At all material times the plaintiff was the registered holder of certain fully-paid shares in an English company. The Public Trustee, as custodian of enemy property, claimed these shares, on the ground that by her marriage the plaintiff had become a German national, and that on January 10, 1920, her property had become charged under the Treaty of Peace Order.

This claim was upheld by Russell, J., on the ground that the principle of $R$. v. Lynch and $E x$ parte Freyberger, though applying to sections 13 and 14, does not apply to section 10 of the British Nationality and Status of Aliens Act, 1914; and that the plaintiff was not merely a German national under the Treaty of Peace Order, but by her marriage became a German subject according to English law. This decision, therefore, involved a decision that the marriage was valid, and invites further consideration of the earlier cases.

Three grounds appear to have been expressed for the decision in $R$. v. Iynch, namely : (1) Section 6 of the old Act (similar to section 13 of the Act of 1914) did not alter the common law by permitting a person to exchange British for enemy nationality, as it contained no explicit statement to that effect. (2) The act of naturalization was an act of treason, therefore no rights could result therefrom. (3) (by Channell, J.), section 6 was not an empowering section, but dealt only with the results of valid naturalization; therefore it did not alter the common law on the subject. In Ex parte Freyberger the first of these grounds appears to have been the ratio decidendi (apart from the Military Service Act). The act was not alleged to be treasonable, though nugatory; and section 14 appears to be of an empowering character. Therefore, even though the applicable section is empowering, and the act is not treasonable, a person is not permitted under such a section to divest himself of British nationality and become possessed solely of enemy nationality.

In view of these considerations there is some difficulty in accepting the differentiation, made by Russell, J., between the effect of sections 13 and 14 and section 10 of the Act, as the basis of the decision. Section 10, as is noted, is, like section 13, not an empowering section; therefore if section 14 does not alter the common law rule as to divesture of British nationality in time of war, section 10 cannot do so. The ratio decidendi is therefore not so much that the effect of section 10 is different from that of sections 13 and 14, as that the marriage was by common law, and therefore now, valid. This was stated by Russell, J., but he gave no reasons. Marriage with an enemy, though it may have been an act that gave comfort to one of the King's enemies was not only not a treasonable act, but not even an invalid one. To arrive at this decision one of two premises must be accepted-

(1) The marriage was not treasonable, because the effect was not to help the King's enemies, as such, but only in a private capacity.

(2) The common law does not invalidate an exchange of British for enemy nationality, provided that such alienage is not the primary object of an act, though it must result therefrom.

This would appear to lead to some modification of the meaning of mens rea.

B. F. M. 